DOI: http://dx.doi.org/10.18290/rh20689-2

\title{
BEYOND EAST AND WEST: \\ WHAT 'LADDER' DID JOHN WU USE TOWARDS THIS GOAL?* \\ (PART ONE)
}

\begin{abstract}
A bstract. John Wu Jingxiong (1899-1986) was a diplomat, scholar, and authority on international law. He was also a prominent Chinese Catholic convert. His spiritual autobiography Beyond East and West (1951) reminds us of the Confessiones of St. Augustine for its moving description of John Wu's conversion to Catholicism in 1937 and his early years as a Catholic. The very title of Wu's autobiography points to his spiritual ideal which let humanity go beyond cultural particularities (be they Western, Chinese or other). John $\mathrm{Wu}$ found wisdom in China's great traditions, i.e. Confucianism, Daoism and Buddhism, pointing to their universal truths that come ultimately from, and are fulfilled in, Christ. The author of this contribution has searched for John Wu's universal traits which go beyond any culture and which he called, metaphorically, a "ladder". He has found a threefold ladder, i.e. that of Christian faith, that of human friendship and human and divine love, and that of natural law.
\end{abstract}

Key words: John $\mathrm{Wu}$; Beyond East and West; spiritual autobiography; Christian faith, friendship; human and divine love; natural law.

Prof. Dr. ZBIgniew WesoŁowsKi - Monumenta Serica Institute, Sankt Augustin, Germany; address for correspondence: Monumenta Serica Institute, Arnold-Janssen-Str. 20, 53757 Sankt Augustin, Germany; e-mail: wesolowski@monumenta-serica.de. ORCID: https://orcid.org/00000003-3449-4830.

* Abbreviations of John Wu's three works:

BEW: Beyond East and West. Sheed and Ward, 1951.

SoL: The Science of Love: A Study in the Teachings of Thérèse von Lisieux. Catholic Truth Society, 1941.

FoJ: Fountain of Justice: A Study in the Natural Law. Mei Ya Publications, Inc., 1971. 
《聖詠譯義》（1946年）

《新經全集》

\section{INTRODUCTION}

John C. H. Wu (Wu Ching-hsiung [Wu Jingxiong] 吳經熊, 1899-1986) was lawyer, juristic philosopher, educator, and prominent Chinese Catholic convert. He was originally a Methodist Christian, baptized in the winter 1917 at the Comparative Law School of China in Shanghai, run by the American Methodist Mission, and converted to Catholicism on December 18, 1937 by conditional baptism at the Catholic Aurora University in Shanghai after reading of the autobiography of St. Thérèse of Lisieux (18731897) (BEW 69 and $B E W$ 242-244). He authored numerous articles and books on various subjects including law, philosophy, and religion. He also translated the Psalms (1946: Shengyong yiyi 聖詠譯義) and the New Testament (1949: Xinjing quanji 新經全集) into Classical Chinese. ${ }^{1}$ In his human and intellectual activities, we find a threefold ladder $^{2}$ which let him reach the realm of "beyond East and West." To be more concretely, we have to do with his ladder of Christian faith, the ladder of friendship and human and divine love, and that of the natural law.

The author of this contribution uses the word "ladder" in a metaphorical way in order to focus on the means of $\mathrm{Wu}$ 's transcendence of spatialgeographical and historical-cultural limitations of human beings.

At the beginning of his autobiographical work Beyond East and West $(B E W)$, John Wu states his human credo:

No, nothing human can be greater than these [that is, Confucianism, Taoism, Buddhism], but Christianity is divine. It is a mistake to regard Christianity as Western. The West may be Christian (I wish it were more so), but Christianity is not Western. It is beyond East and West, beyond the old and the new. It is older than the old, newer than the new. It is more native to me than the Confucianism, Taoism and Buddhism in whose milieu I was born. I am grateful to them, because they have served as pedagogues to lead me to Christ. Christ constitutes the unity of my life. It is thanks to this unity that I can rejoice in being born yellow and educated white. (12)

\footnotetext{
${ }^{1}$ The source text for his translation of the Psalms was the English translation (Translation of the Psalms and Canticles with Commentary. Sands and Co., 1901) done by James M. Swiney (1865-1932). The source for his translation of the New Testament is not so clear. However, it must have been an English version of the Bible close to the Latin Vulgate. For the Chinese version of his translation of the Psalms and New Testament, see http://jesus.tw/Psalms and http://jesus.tw/New_Testament (accessed on 21 January 2020).

${ }^{2}$ All bold letters are done by the author of this contribution, if not otherwise noticed.
} 
At the end of his spiritual autobiography, John $\mathrm{Wu}$ also says:

Our pilgrimage is therefore neither eastwards nor westwards, but inwards; and this is what I call moving beyond East and West.

It is not fair to Christianity to call it "Western." Christianity is universal. In fact, the West has something to learn from the East, for, on the whole, the East has gone farther in its natural contemplation than the West has in its supernatural contemplation. (BEW 350)

With these passages, we catch the core of John Wu's spiritual thought which is built upon various opposites, such as east versus west, Christianity (Catholicism) versus Chinese religions (Daoism, Buddhism, and Confucianism), human versus divine, and natural versus supernatural. In this context, there is also his own clear choice and argumentation: Divinity overarches humanity, universality overcomes particularity, and inwardness surpasses the distinction between east and west. "Our pilgrimage" 3 — his basic metaphor for human life - or even better - for a human soul ${ }^{4}$ is also articulated. This simile is used for the human being as the pilgrim in this world. In many mystical traditions, especially in Christianity, man is compared to a pilgrim. Thus, John Wu understood his life as a journey with a sacred purpose and a holy place to end, that is, with God Himself: "Well, one does not become a saint and go to Heaven by cleverness, while sanctification is my sole

\footnotetext{
${ }^{3}$ That is a "Homo viator" ("pilgrim man") as man on his way towards finding God; cf. Marcel. Cf. the phrases "... I am not writing an autobiography but only the story of my spiritual pilgrimage" ( $B E W 118)$, "my juristic pilgrimage" (BEW 123). "spiritual wanderings" (BEW 149), Cf. "Was I not a traveler, a lonely wanderer in desolate world? Did I not write: Travelling has its advantages, the chief among which is that it drives home to you that you are but a traveler on earth. Your wife, your children, your friends are really no more than your chance acquaintances. Your own body or even your personality is something you have casually acquired. You are a guest in a world without a host, for all the people you meet are as much guests as you are" (BEW 305).

${ }^{4}$ Cf. $B E W 110$ (belief in God and immortality of the soul), $B E W 171$ (“... a keen insight into my soul"), $B E W 192$ (“... the physiognomy of the Chinese soul ..."), $B E W 207$ (“... a true peace of soul"), $B E W 260$ ("But our souls are immortal") etc.

${ }^{5} \mathrm{Cf}$. this passage: "Form me the 'transcending spiritual repose' was not to come until the winter of 1937, when I embraced the Catholic Church. In the meantime I remained as restless as ever. I tried to find one substitute for God after another, but found no peace. Without his knowing it, it was partly due to his [that is, Justice Holmes] influence that my faith in Christianity had been diluted. I still retained some faint belief in God and the immortality of the soul" (BEW 110); or another instance: "Yes, as I look back upon these fifty-odd years of my life, it appears all of one piece, the keynote being Love. My whole life has been surrounded by God's Love. All the scattered leaves of my life have been gathered together by His loving hand and bound into an harmonious volume" (BEW 345).
} 
ambition now, and the Beatific Vision my sole objective"" (BEW 323). In his Fountain of Justice (FoJ), he said this truth in a following way: “... the ultimate end of law is identical with the ultimate end of a man, which is union with God" (FoJ 245).

To my knowledge, John $\mathrm{Wu}$ in his $B E W$ only once used our key word "ladder": "He [Fr. Nicholas Maestrini] initiated me into the beauties of the Daily Missal. He expounded the philosophy of Holy Mass as the ladder of perfection" ( $B E W$ 253). Another word which could approach our image of "ladder" is "bridge." With this word "bridge" is John Wu very close to our metaphor of ladder:

God has long ago thrown a living and lifesaving Bridge from Heaven to earth, but man has ignored the divine Bridge while trying hectically and in dead earnest to build his own bridge from earth to Heaven! Man now has too much cleverness, and too little wisdom! How can one reach the Infinite by finite means? (BEW 84)

With "a living and lifesaving Bridge" is for John Wu meant Jesus Christ. To Christians including John $\mathrm{Wu}$, Jesus Christ can be seen as being the ladder which bridges the gap between Heaven and earth. Jesus presents himself as the reality to which the ladder points. As Jacob saw in a dream the reunion of Heaven and earth (Genesis 28:10-19), Jesus brought this reunion, metaphorically the ladder, into reality. Thus, Jesus Christ is the perfect "ladder", because Jesus Christ is God who came to earth to save humanity. Jesus refers to himself as this ladder in John 1:51: "And he [Jesus] said to him [Nathanael], 'Truly, truly I say to you, you will see heaven opened, and the angels of God ascending and descending on the Son of Man."'

In the context of John 1:58, we think first of all about Jacob's ladder which is a ladder to Heaven dreamt about by the biblical Patriarch Jacob during his flight from his brother Esau. Thus, this ladder dreamed by Jacob is for Christians a representation of Christ, in His person, as God-man; who, as God, was in Heaven, whilst he, as man, was on earth; and in his office, as Mediator between God and man, made peace between them both.

His thought of Christ as the only Divine Bridge, John Wu reiterated in $B E W$ on pp. 222-223:

\footnotetext{
${ }^{6}$ The metaphor of the ladder is different from that of the bridge, because the first one point out to the vertical and the bridge - to the horizontal. That is why they should refer to different realities. However, the usage of John $\mathrm{Wu}$ - one might criticize it as "not precise enough" makes the two concepts more or less to synonymous!
} 
Deep down in me, I felt a yawning abyss of nothingness, which only God could fill, and I had not found God. I did not find God, because I had drifted away from Christ, the only Divine Bridge that God had built from Heaven to earth. Having drifted away from Christ, my faith in God was fading rapidly, and with it the belief in the immortality of the soul.

\section{WHY "MOVING BEYOND EAST AND WEST"?}

Here we want to cite once again two very intriguing statements of John Wu: (1) "Our pilgrimage is therefore neither eastwards nor westwards, but inwards; and this is what I call moving beyond East and West" ( $B E W 350)$ and (2) "[...] the ultimate end of a man [...] is union with God" (FoJ 245). What does this inwardness or inward character of human pilgrimage mean to John Wu? Of course, this means to him human inner nature, spirituality; yes, a mystical character of human life and existence. He himself was a mystic, and he understood himself also in this way:

As for me, who am a carefree mystic, the currents of time have touched me but slightly. Even in my darkest days, I have felt a secret joy bubbling from the fountain of my heart, so much so that I have often recalled the striking words of St. Paul: "as dying and behold, we live, as chastised but not killed, as sorrowful yet always rejoicing, as poor yet enriching many, as having nothing yet possessing all things" (2 Cor. 6.9-10). (BEW 63)

He was also a teacher of Christian mysticism:

One is the Psalm of the Good Shepherd [no. 23], which has revealed to me the three stages of interior life. My whole course on Christian Mysticism, which I have been giving in the School of Religion of the University of Hawaii, ${ }^{7}$ is based upon this one Psalm. The first stage, which the spiritual writers usually call the purgative way or the age of the beginners, is symbolized by the following verses:

The Lord is my shepherd: I shall want for nothing.

He makes me lie down in green pastures.

He leads me to waters where I may rest. He gives refreshment to my soul.

The second stage, which is usually called the illuminative way or the age of the proficients, is symbolized by:

He guides me along right paths for his name's sake.

Although I walk in a darksome valley,

\footnotetext{
${ }^{7}$ In June, 1949, John Wu became Visiting Professor of Philosophy at the University of Hawaii, where he wrote his autobiography $B E W$.
} 
I shall fear no evil, for thou art with me.

Thy rod and thy staff: they comfort me.

The third stage, which is the unitive stage or the age of the perfect, is symbolized by:

Thou preparest a table for me before the eyes of my foes;

Thou anointest my head with oil;

My cup brims over.

Goodness and kindness will follow me all the days of my life,

And I shall dwell in the house of the Lord days without end. $(B E W 303-304)^{8}$

The teaching of the three stages (or ways, or states, or aspects) of Christian spiritual life has a long history. ${ }^{9}$ What is here important is the fact that John $\mathrm{Wu}$ discovered and witnessed this spiritual and mystical growth in his own life. These three, i.e., purgative, illuminative, and unitive, stages, are also used for the classification of the degrees of Christian perfection, or for measurement of the advancement of souls in the supernatural life of grace during their sojourn in the world. John Wu's deepest insight as his answer to God's overwhelming grace, understood according to his $B E W$, was to conceive his own human life and existence something as follows: The Christian is born into this world, and dwells herein for a certain time. But he is not of the world. Thus, as Jesus said: "They [i.e., His disciples] are not of the world, even as I am not of the world" (John 17:16). The world is of no avail to him; the Christian is a stranger and a sojourner in it. The true riches

\footnotetext{
${ }^{8}$ This threefold way of the Christian spiritual life, John Wu mentioned earlier in his $B E W$ 186: "[...] when I read in a Buddhist Classic: 'Avoid all evil, cherish all good, and keep the mind pure. This is the teaching of all the Buddhas'; I said to myself, 'How similar this is to three ways of the Christian spiritual life: the purgative, illuminative and unitive!' When I read Confucius' program of education of his pupils: 'First arouse their interest in wisdom by means of poetry; then establish their character by making them practise the moral rules; finally, harmonize their personality by means of music'; it reminded me of the Psalm of the Good Shepherd. The spheres are wide apart as heaven and earth, but the stages of progress are quite similar, for the simple reason that even grace has to work upon the natural and psychological apparatus of man. With regard to the wisdom of the East and Christian wisdom, God has given to my mind an organic unity of transparent differences."

${ }^{9}$ The earliest occurrence in Christian writing of the terms purgation, illumination, and union seems to have been found in Pseudo-Dionysius (fl. c. 550), who applied them to the mystical experience. According to Dionysius, the three acts are thearchic (i.e., given by God) and hierarchic (i.e., ordered) ways to mystical union. They describe both complementary functions and successive activities; as successive they correspond to the three stages of mystical growth set down by Evagrius Ponticus, also called Evagrius the Solitary (345-399 AD). Cf. Hierarchy and the Definition of Order in the Letters of Pseudo-Dionysius: A Study in the Form and Meaning of the Pseudo-Dionysian Writings by Ronald F. Hathaway and Evagrius Ponticus and Cognitive Science: A Look at Moral Evil and the Thoughts by George Tsakiridis.
} 
of the Christian on earth are grace, close communion with God, and all that fosters the supernatural life within him. Those things only are really evil which weaken that spiritual life, or deprive him of it.

Thus, we should be able in the following to reconstruct some aspects of John Wu's threefold path of mystical growth, ${ }^{10}$ i.e., purgative, illuminative, and unitive states. ${ }^{11}$ Of course, we will not be able to exemplify a classical Christian mystical theory as fulfilled in the life of John Wu. What we are able to say is that "moving beyond East and West" points out to the direction of John Wu's Christian spiritual growth which transcends spatial-geographical and historical-cultural limitations of human beings.

In this context, we would like to quote John Wu's explanation of the reason for writing $B E W$ :

To write an autobiography or a book of confessions when one is still a babyfor, after all, life begins at fifty — is, to say the least, a hazardous undertaking. I should never have started this book were it not for the persistent pressure of my friends, especially my dear confessor. Father Nicholas Maestrini, who has been praying for it more than ten years. Other priests, including Father Pasquale d'Elia ${ }^{12}$ and Father F. Legrand, have also pressed me to do it. Their reason is, perhaps, that the capturing and taming of one dragon might lead to

${ }^{10}$ Christian mystics have been described as pursuing a threefold path corresponding to body, mind, and soul, that is, purgative, illuminative, and unitive aspects of their spiritual life. The first, purgative aspect or purification focuses on discipline of the human body. It emphasizes prayer at certain times, either alone or with others, and in certain postures, often standing or kneeling. There are other disciplines required like that of fasting and alms-giving, the latter including those activities called "the works of mercy," both spiritual and corporal. The second phase, the path of illumination, has to do with the activity of the Holy Spirit enlightening the mind, giving insights into truths not only explicit in the Bible and the rest of the Christian tradition, but also those implicit in nature and everyday experiences. The third phase, usually called contemplation refers to the experience of oneself as in some way united with God. The experience of union varies, but it is first and foremost always associated with a reuniting with Divine love. Cf. Healey.

${ }^{11}$ On $B E W 351-352$, John Wu deplores the low level of spiritual education of the Christian in the West: "To take just one instance, the average Buddhist in China knows something about the three stages of Abstention, Concentration and Wisdom; while the average Christian has no idea of the three ways, the purgative, the illuminative and the unitive. The spiritual education of the Christian is sadly neglected."

${ }^{12}$ In $B E W$ is this name wrongly written as: d'Elie. Pasquale d'Elia (1890-1963) was an Italian Jesuit. He was in Zikawei (Xujiahui), near Shanghai, China, from 1913 to 1917. Later he completed his theological education at Woodstock, Maryland, and Hastings, England. After his return to China in 1923, he became a professor of English and philosophy at Aurora University in Shanghai until 1930. Since 1933 he was professor at the Gregorian University in Rome in 1933. There he instituted a chair of missiology. He is best known for his publications about Matteo Ricci, especially his annotated edition of Ricci's manuscripts known as Fonti Ricciane. 
the capturing and taming of all the other dragons. Of course, they know as well as I do that everything depends upon the grace of God, but they think that the story of my conversion may throw some light on the spiritual physiognomy of my countrymen and give the missioners ${ }^{13}$ some hints on the ways of approaching them. Moreover, as I was the worst of the prodigal sons, my return sets the mercies of the Almighty Father in the clearest relief. [...] To my mind, one Hail Mary said devoutly would lead more souls to Christ than a dozen autobiographies. ${ }^{14}(361)$

Thus, John $\mathrm{Wu}$ was to his Western friends and missionaries a dragon with Chinese spiritual physiognomy which was caught and tamed by the grace of God. We all know the symbolic difference between Christian and Chinese understanding of dragon. The Chinese dragon (long 龍) is the highest-ranking animal in traditional China, associated with the emperor and hence it stands for power and majesty. It is still recognized and revered among the Chinese. Its origins are vague, but its "ancestors can be found on Neolithic pottery as well as Bronze Age ritual vessels" (Welch 121). In the New Testament the word "dragon" is found only in Book of Revelation $(12: 3,4,7,9,16,17$, etc.), and is there used metaphorically of "Satan", i.e., "the opposer." 15 This Christian meaning is also present in $B E W$, at least I found one place:

One evening in 1944, when we were in Chungking, I quarreled with my wife in the very midst of our family Rosary. A shame on me! [...] Suddenly I heard the voice of my second son Edward, who was now leading the Rosary in my stead, calling out to the rest of the kids, "Let us all kneel and pray to Our Blessed Mother for Daddy!" I felt as though the poisonous dragon within me was trampled under foot by Our Lady. Before the rosary ended I had slipped back quietly, and found myself kneeling humbly behind my little ones. (141-142)

Let us turn to the spiritual physiognomy of the Chinese soul as understood by John Wu:

There is in the bosom of every Chinese a secret pride, which can only be melted by the fire of love, but cannot be uprooted by a surgical operation. You may rough-handle him, you may beat him to his knees; but you can never win

\footnotetext{
${ }^{13}$ A less common name for missionaries.

${ }^{14}$ This humble expression of John $\mathrm{Wu}$ is for me an example of the purgative path of his spiritual growth. The characteristic virtue of this path or state is humility, by which one is made sensible of his or her own weaknesses and the need for a total dependence upon the grace of God.

${ }^{15}$ The Book of Revelation twice refers to "the dragon, that ancient serpent, who is called the devil and Satan" (12:9, 20:2). The Book of Revelation also refers to "the deceiver," from which is derived the common epithet "the great deceiver."
} 
his heart by such means. On the contrary, his knees may kneel, his heart will ever rebel. But if you treat him nicely, he is too sensible to take advantage of your kindness and generosity. We must remember that he belongs to an old nation rich in experience and worldly wisdom. You can only make him humble by making him generous, and you can only make him generous by being generous yourself. (BEW 352)

What are other characteristics of the Chinese soul? John $\mathrm{Wu}$ finds its monastic tradition:

One of the greatest charms of the Catholic Church for the Chinese soul is its monastic tradition. The Chinese people are on the whole attached to the world; but they have a secret admiration for those who have heroically sacrificed all their worldly pleasures and relations in order to devote themselves to a life of union with God. At the bottom of their heart, the Chinese realize that all honors and riches will soon pass without leaving a trace; and therefore they admire those who abandon what is temporary in single-hearted pursuit of what is eternal. This is why, although living in the world, my heart is with those who are living in cloisters. (BEW 353-354)

Another characteristic of the Chinese soul is its syncretism which for him means the spirit of tolerance:

The Chinese people are syncretically minded. Men of different religions or denominations have no prejudices against one another at all. In fact, if a Catholic tries to live up to his professions, all people will respect him. President Chiang Kai-shek, a Methodist, co-operated wholeheartedly with me on the translation of the Psalms and the New Testament. In the history of China, many beautiful friendships have existed between men of avowedly different faiths. ( $B E W 354)$

And what could be "the most characteristic quality of the Chinese soul"? John Wu's answer is as follows:

Perhaps, the most characteristic quality of the Chinese soul is a certain playfulness flowing spontaneously from an interior harmony. At his best, a Chinese is in tune with the Universe. The rhythms of his life are in perfect accord with the cosmic rhythms; or, rather, the two blend into one. Whether he is a Confucianist, a Buddhist or a Taoist, the feeling of oneness with the Universe forms, as it were, the inarticulate substratum of his soul. This feeling is a direct aesthetical intuition beyond words and images. ( $B E W 355)$

John Wu also asked the following question: 
[...] what is the most fundamental characteristic of Chinese spirit? To my mind, it is the union of the abstract with the concrete, of the universal with the particular, of utmost unearthliness with complete earthliness, of transcendental idealism with a matter-of-fact practicalness. This union is not a matter of theoretical synthesis, but a matter of personal experience. ( $B E W 182)$

In John Wu's characterization of the Chinese soul, we cannot omit the following:

I think it is not too much to say that in the Chinese soul one quality stands out above others, and that is the sense of gratitude. The very institution of "ancestor-worship" (this is a misnomer, for in reality it is nothing more than the remembrance of one's ancestors) is based upon the sentiment of gratitude towards the origin of one's physical being. This feeling of gratitude can easily be transferred to its proper place, that is, in our relations with God, the Father of all mankind, the Living Source of all things physical and spiritual. When a Chinese is converted, it is but natural that gratitude should constitute the dominant note of his spirituality. I think it is true in my own case. ( $B E W 346)$

In comparison with Christianity, John Wu was critical of Chinese culture, as the following passage says:

However, there is no denying that without the light of Revelation a Chinese is in danger of becoming a fatalist, just as an Occidental who has forgotten his Christianity is in danger of becoming an activist. (BEW 348)

Thus, let us in this context reiterate John Wu's basic spiritual insight:

It is not fair to Christianity to call it "Western." Christianity is universal. In fact, the West has something to learn from the East, for, on the whole, the East has gone farther in its natural contemplation than the West has in its supernatural contemplation. (BEW 350$)$

John Wu's life was the constant pursuit of communion with and conscious awareness of God's presence as the Ultimate Reality, or Spiritual Truth through direct experiences and insights in his life. This is a way of a mystic.

Before we go to a comparative dimension of East (China) and West (therein also Christianity), we will cite a very interesting passage:

[...] a slow tempo of life [is] that [which] a Chinese likes. Any hurried movement is disconcerting to him. In this, again, I am a Chinese of the Chinese. ${ }^{16}$ (BEW 351)

\footnotetext{
${ }^{16}$ Here John Wu echoes Saint Paul's words written to Philippians 3:4-6 where he described his Jewish heritage. In this passage Paul says he was "circumcised on the eighth day, of the people of Israel, and the Tribe of Benjamin, a 'Hebrew of the Hebrews.'”.
} 
Thus, John $\mathrm{Wu}$ as "a Chinese of the Chinese" must have suffered very strongly under differences and tension between China and the West. His credo in the unity of mankind, he expressed as follows:

Humanity is one in spite of the national boundaries and underneath the differences of color. The differences between races are skin-deep, but the unity of mankind lies in the innermost heart of hearts. (BEW 218)

It is this spiritual dimension, this human inwardness, man's inner or interior life that is the direction of "moving beyond East and West":

The evolution of music from melody to harmony is symbolic of the development of human society and of the growth of man's inner life. (BEW 210)

In his short part "East and West" (Chapter 14: "Mental Roamings") in his $B E W$, he said:

East has more of the feminine, and the West more of the masculine qualities. The hope of the future depends upon their mating, and the mating season is on even now! (218)

It is interesting to contrast cultures according to the human biological categories of femininity (womanliness, womanhood) and masculinity (manliness, manhood). ${ }^{17}$

Behavioral traits generally considered feminine include gentleness, empathy, and sensitivity. The qualities ascribed to manliness are courage, bravery, and resolve. Traits associated with femininity or masculinity often vary depending on time, location and context, and include a variety of social and cultural factors. For John $\mathrm{Wu}$, this distinction must have echoed the Chinese bipolarity of yin und yang. ${ }^{18}$ In Chinese philosophy, the concept of yin-yang 陰陽 is used to describe how contrary or opposite forces are interconnected and interdependent in the natural world and how they give rise to or destroy each other when they interrelate. Except for the natural bipolarity such as above-mentioned female and male, there are those of dark and light, low and high, cold and hot, water and fire, and so on.

\footnotetext{
${ }^{17} \mathrm{Cf}$. Vetterling-Braggin (ed.). See also the very special way of reiterating the words of Fr. Hernandez about St. Teresa of Avila: “... He [i.e., the Holy Spirit] raised Teresa of Avila, a woman who was a man. Nor is it for nothing that his time He has raised "a baby who is an old man" (SoL 34-35).

${ }^{18} \mathrm{Cf} . B E W$ 161: “[...] you can play the feminine part to the opening and shutting of the door of heaven, that is, you can respond with perfect docility and spontaneity to the rhythms of the cosmos."
} 
Here I would like to cite an intriguing passage from $B E W$ concerned John Wu's search "for a Mother":

All my life I had been searching for a Mother, and at last I had her in the Catholic Church, and this in a triple sense. God is my Mother, the Church is my Mother, and the Blessed Virgin ${ }^{19}$ is my Mother; and these three Mothers have merged into one Motherhood, in which I live, move and have my being. [... $]^{20}$

One of the charms of the Catholic Church is that this feminine element in the Character of Jesus is institutionally represented in the person of the Blessed Virgin. It is indeed the True Church, for it embodies the Personality of the Founder in Its fullness. (BEW 244)

In Chapter 3: "My little mother" (pp. 26-32) of his $B E W$, John Wu begins as follows:

God gave me two mothers, one to bear me and another to bring me up. The one who bore me I shall call here my little mother; the other who brought me up I shall call my big mother.

His little mother died when John was only four years old. About his big mother, John $\mathrm{Wu}$ wrote as follows:

It is not easy for me to write about my big mother. If I am asked who of all human beings is dearest to me, I would answer without the slightest hesitation that it is my big mother. I have dreamed of her more often than of any other person. I have wept more tears in memory of her than of anyone else. (BEW 33)

One has not to be a psychologist to imagine the impact of the death of a parent, especially of a mother, for our life. Psychological research has shown that a person's age affects his or her ability to cope with the death of a parent (Harris). The loss affects adult personality development, a sense of security, and relationships with the surviving parent and significant others. Besides, younger children, as it was the case of John $\mathrm{Wu}$, are more at risk for depressive symptoms than older children (Raveis, Siegel, and Karus 165-180). His big mother also died, when he was an adolescent of 15 years.

${ }^{19}$ Cf. BEW 358: "[...] the Catholic devotion to the Blessed Virgin has been prefigured in all the religions of the East. The Oriental love for the Mother - whatever form she may take - is apt to be a lifelong passion. This passionate affection for the Mother runs through all the religions of the East like a common strain."

${ }^{20} \mathrm{Cf}$. Acts 17:28: "For in him [God] we live and move and have our being." 
Thus, we want to conclude that John Wu's "search for a Mother" has its "Sitz im Leben.",21

Let us turn back to John Wu's comparative thoughts on culture in East (China) and the West. He said:

Both China and the West have been searching for happiness, but their methods are fundamentally different. On the whole, we try to cut down our desires, while the Occidentals try to amplify the means of satisfying them. (BEW 218-219)

He went on to say with some amusement:

The difference between the East and the West is only the difference between tea and coffee. And yet there are not lacking tea enthusiasts among Westerners. (BEW 219)

Sometimes John Wu's judgments were more serious statements:

All civilization is a disease; and there are different types of civilization as there are different kinds of disease. Chinese civilization is beriberi ${ }^{22}$; Western civilization is wandering sickness. ${ }^{23}$ The former is tuberculosis, ${ }^{24}$ the latter typhoid fever. ${ }^{25}$

Chinese civilization is a museum, Western civilization a circus, Indian civilization a graveyard. You go to a museum for curiosity, to a circus for excitement, and to a graveyard for meditations. (BEW 219)

${ }^{21}$ The German term "Sitz im Leben" is a phrase firstly used in Biblical criticism with a rough meaning of "setting in life."

${ }^{22}$ Beriberi (Chin.: jiaoqibing 脚氣病) is a nervous system ailment caused by a deficiency in vitamin B1 (thiamine) in the diet. Thiamine is involved in the breakdown of molecules such as glucose and is also found on the membranes of neurons. Symptoms of beriberi include severe lethargy and fatigue.

${ }^{23}$ According to the Pima Indian healing system, disorders believed to occur because of impurities wandering into and throughout the body (Mosby's Dictionary of Complementary and Alternative Medicine, Elsevier Health Sciences, 2005); medical-dictionary.thefreedictionary.com/wander ing+sickness; accessed on 18 July 2019).

${ }^{24}$ Tuberculosis (TB) typically attacks the lungs, but can also affect other parts of the body. It is spread through the air when people who have an active TB infection cough, sneeze, or otherwise transmit their saliva through the air. The classic symptoms of active TB infection are a chronic cough with blood-tinged sputum, fever, night sweats, and weight loss.

${ }^{25}$ Typhoid fever (or simply typhoid) is a common worldwide bacterial disease, transmitted by the ingestion of food or water contaminated with the feces (as excrement, is a waste product from an animal's digestive tract expelled through the anus) of an infected person, which contain the bacterium Salmonella typhi, serotype Typhi. 
He mentioned once:

Westerners are seriously humorous, but we are humorously serious. While they are better acquainted with the misery of being funny, we are better acquainted with the fun of being miserable. (BEW 221)

John Wu's own attempt in his life was to "move beyond East and West," the others have admitted him "a living synthesis of the East and the West, a synthesis like a seamless cloth" (BEW 323). It was Dom Lou ${ }^{26}$ who gave the Nihil Obstat for John Wu's translation of the New Testament in 1948 and wrote to Monsignor Lukuang ${ }^{27}$ the following words:

I don't see any reason why this translation should I not become the authorized version. His use of the classical phrases and idioms furnishes the key to a living synthesis of the East and the West, a synthesis like a seamless cloth, like he pieces of coal melted into one fire in the furnace of Divine Love. Could all this have been attained without the inspiration of the Holy Ghost? (BEW 323)

F.J. Sheed in his "A Note of Introduction" to $B E W$ made a very intriguing witness of John Wu. He said:

He is at once so totally Catholic and so totally Chinese - so Catholic that you would think generations in the Faith must have gone to his making; so Chinese that you know he brought his whole racial and cultural heritage with him into the Church, intact; $[\ldots]$

So that there is a third totality to add to the other two. He is totally Catholic, totally Chinese, and totally himself. Of that self I need say nothing. It is all here in the book [...]. (BEW VII-VIII)

So let us now turn to John Wu's "total Catholicism."

${ }^{26}$ That is Lou Tseng-Tsiang (Lu Zhengxiang 陸徵祥 1871-1949). He was a Chinese diplomat and a Roman Catholic monk. During his early life, he was twice Premier of the Republic of China and led his country's delegation at the Paris Peace Conference of 1919. Cf. Keegan 172-185.

${ }^{27}$ Stanislaus Lo Kuang (Luo Guang 羅光, 1911-2004) was archbishop (since 1961 bishop of Tainan and 1966 archbishop of Taipei) who spent most of his life in Taiwan. He was also Rector (President) of Fu Jen Catholic University (1972-1992). 


\section{MEANS OF “MOVING BEYOND EAST AND WEST"}

The reading of John Wu's works gives us an above-mentioned threefold ladder for reaching the realm of ,beyond East and West." One ladder is that of Christian faith as pure grace of God. This ladder is given by God Himself from heaven as a pure gift to a human being. This ladder given from above can only be accepted or refused by a human person. The second ladder is that of human or natural and divine love. This ladder is constructed both by a human being with his or her natural ability of love and God who has first loved us. Thus, we could say that this is the construction of a bridge with pieces of ladder going from earth to Heaven and from Heaven to earth. The third ladder is that of natural law which depends on a sound human reason. This kind of a ladder is totally a work of human ability to know and reason.

\subsection{The ladder of Christian faith}

After his conversation to Christianity, Christian faith was John Wu's most important ladder, that is, a true Christian faith as a pure gift and an undeserved grace given by God Himself:

Grace is all. Nobody can come to Christ without first being drawn to Him by the Father (John 6:44), nor can any one come to the Father except through Christ, nor can any one be sanctified except through the Sacraments of the Church, which are the regular channels of grace. It is no more than the truth to say that ever since I became a Catholic, my life has been a continual feast, a feast that satisfies without satiating. Adversities and tribulations there are aplenty, but even these are sweet, or rather they serve to bring out the marvelous sweetness of God. (BEW 9)

This is the credo of a man who was found by God and changed by His grace. When he first became a Methodist, ${ }^{28}$ he understood it as follows:

${ }^{28} \mathrm{Cf} . \mathrm{BEW} 75$ : "For the first few years after my conversion to Methodism, I was quite a zealous Christian, praying constantly and visiting the poor." See also $B E W$ 77: "As my own faith was not firmly rooted, I gradually drifted away from my first love for lack of a congenial religious milieu. Moreover, my juristic and philosophical preoccupations diluted more and more what little faith I had got, with the result that I forgot all about the doctrine of the Trinity, and became a Unitarian without my knowing it. I began to look at Christ as a mere man, a human teacher whose extraordinary personality and lightning-like flashes of moral insight continued to fascinate me. I adored Him in the spirit of hero-worship, which I had imbibed from Thomas Carlyle. As a freethinker I no longer cared whether He was born of a Virgin, or whether He rose again from the dead, or whether He actually worked miracles. If He was not God, He was all the more admirable and worthy of imitation. All questions of dogma were relegated to the background." 
When I became a Christian in 1917, I felt as though I had become an emperor overnight, because now I could worship God directly, having been empowered to be a son of God. My embracement of Christianity was a tremendous spiritual revolution on a par with the political revolution which had changed an absolute monarchy into a republic. $(B E W 188)^{29}$

However, Protestantism was only the first stage of John Wu's encounter with Christianity. Here we quote some words of his criticism against Protestantism:

Protestantism carries the seed of disintegration within its own bosom. It began by protesting against authority; it is bound to end by protesting against itself. At least this was what happened to me. My individualism, together with my irrationalism and sentimentalism, had reached such a point that I had become like a lonely disembodied soul wandering through an empty universe and trying agonizingly to find a new body for itself. I was completely denuded; only the grace of God could have re-clothed me with Christ, with the whole Christ: True God and True Man. Else I should have done away with my life like another Werther. ${ }^{30}(B E W$ 82)

John Wu's search for God, or probably better: God's search for John Wu, was a very difficult task, and eventually it had to be-as John Wu understood it - God Himself to give him a ladder to climb upon:

${ }^{29}$ In this context, John Wu explained his view why the Chinese did not worship God directly: "The answer is that they regarded God as too high for them, and that, just as an ordinary subject did not deal with the Emperor directly but had to obey the orders of his immediate superiors, so the ordinary man, in his religious life, had just to pay his homage to the minor deities who were appointed by the Supreme Deity to supervise his daily life." (BEW 187).

${ }^{30} \mathrm{Cf}$. The Sorrows of Young Werther (German: Die Leiden des jungen Werthers) is a novel by Johann Wolfgang von Goethe, first published in 1774. This work was an important novel of the Sturm und Drang period in German literature, and influenced the later Romantic literary movement. The end of the novel plot is that Werther shoots himself in the head, but does not pass away until 12 hours after he has shot himself. He is buried under a linden tree, a tree he talks about frequently in his letters, and the funeral is not attended by clergymen, Albert or his beloved Lotte. Cf. $B E W$ 241: "Why did I not commit suicide? Well, I wrote somewhere in my diary: 'I am too pessimistic even to commit suicide, because I really do not believe that the next world will be better than this.' So far as I know, two principal causes had brought me to this state, one interior and the other exterior. Interiorly, I had desired Paradise but, owing to my own sins, found myself in hell. Exteriorly, I had desired peace and harmony but found nothing but war and discords." Or see $B E W$ 231: "'Enough, enough. Cardinal Newman!' I said, 'I know better than you do that the human race is out of joint with the purpose of its Creator. But tell me what is the remedy?' Then I came across this remarkable sentence [in his Apologia Pro Vita Sua]: 'Since the world is in so abnormal a state, surely it would be no surprise to me, if the interposition were of necessity equally extraordinary - or what is called miraculous.' In the margin of the book, I wrote: 'An extraordinary disease requires an extraordinary remedy!'” 
Sometimes, it is true, I did think of God. For instance, my diary of October 13, 1936, contains a striking confession:

I have tried one substitute for religion after another; all of them have failed to satisfy me. Friendship? Well, I have found my friends wanting in perfection. Books? ${ }^{31}$ Well, the more learned you are, the more you are vexed by the insipidity of the wisdom of man. Science? It is only a part of Religion, that part which makes us as cunning as a serpent. Official life? The higher you climb, the emptier your life becomes. Money? I used to earn lots of money, but that didn't make me any happier. Health? It is good, but only as fundation to build your temple of life. Fame? I have had my share of it, but the only advantage is that my wife can go shopping without bringing cash. Girls? I have had enough of them. Children? Yes, they are charming, but they take me to be a toy capable of making grimaces and provoking laughter. Animals? They make good company and remind me of my origin. But they can give little more. Gardens? They are beautiful, but I hear echoes of the miseries of life outside. Self-reliance? But I am a slender reed.

After a long period of mental wandering, I have finally come back to God. God includes all pleasures of life and heightens their meaning. He is the ideal friend who knows your heart better than you do yourself; $\mathrm{He}$ is the meaning of all books worthy of the name, the overtone of music, and the very subject-matter of all science and philosophy. He teaches you how to execute your official duties; He teaches you how to make use of money and other material things; He transforms fame into a vessel of love; He sanctifies girls to be your mothers and sisters; He teaches you how to learn from children and animals; He inspires you to make a garden of the world; He strengthens moral and intellectual fibre and leads you to shed the cocoon of self. (BEW 206-207)

We see in John Wu's autobiographical notes quite a long list of substitute or surrogate religions ${ }^{32}$ possible in every human life. This reveals us a particular aspect of John Wu's intellectual life and many human beings todaya great longing for personal existential synthesis! ${ }^{33}$

\footnotetext{
${ }^{31}$ Here we should specifically add law as his substitute of God; cf. chapter 10 of $B E W$ is “"Law Is My Idol”" (pp. 107-132).

${ }^{32}$ Cf. Gentile, chapters 3-4. Luigi Sturzo, Adolf Keller, Paul Tillich, Gerhard Leibholz, Waldemar Gurian, Eric Voegelin, Raymond Aron and Walter Benjamin, and others saw the reaction to religion in modern time as a response to the existential void and Nihilism caused by modernity, mass society and the rise of a bureaucratic state. In "political religions" of the 20-century ideologies, Gentile saw "the rebellion against the religion of God" reached its climax. The abovementioned intellectuals also described such ideologies as "pseudo-religions," "substitute religions," "surrogate religions," "religions manipulated by man" and "anti-religions."

${ }^{33}$ Cf. $B E W 139$ ("a working synthesis of individual liberty and family stability") and $B E W$ 216 ("Analysis and Synthesis"). As to John Wu's attempt at a synthesis in the philosophy of law, see $B E W$ 98: "Stammler's emphasis was on the conceptual or logical aspects of law, whereas
} 
Had I not reached some kind of a synthesis? How was it then that I was still writing as one who had not found his resting place? The truth is that no merely pragmatic or naturalistic solution could satisfy the deeper needs of my soul. A true synthesis could only be attained when one is elevated by grace from the conflicting opposites to a sphere higher than both of them. (BEW 139-140)

Yes, for John Wu it is God's grace to know Him, that is, the grace of Catholic faith, which is a ladder to come back to Him:

Grace has transformed me, and God forbid that I should ever return to my vomit!" (BEW 144). That is why, John writes:

The great mission of Christ is to lift us from the natural sphere to the supernatural sphere, to free us from our bondage to the dialectical process of time. What is more, by His grace we are enabled to reach the Beyond by riding the chariot of mutability. For, Christ has also declared: "Blessed are ye that weep now: for you shall laugh." Here we are no "longer in the natural sphere, but in the sphere of grace. We can sail safely across the ocean of time and reach the shore of Eternity, because we have welcomed Jesus into our boat. (BEW 144)

"[O]ur bondage to the dialectical process of time" - this phrase brings to us a special existential and intellectual feature of John Wu's life, that is, his sensitivity to everything within this bondage to the dialectical process of time. ${ }^{34}$ That which is under the bondage to the dialectical process of time is paradox, is a series of opposites, a "series of counterpoints" (BEW 127 after his friend Russell Cades), and this all is the main trait of the finite. ${ }^{35}$ This is a human part of John Wu's dialectical method of truth-seeking, the rest, that is, the actual ladder which helps to lift to the sphere of grace comes from God:

Holmes' emphasis was on the perceptual or psychological aspects. They were, thus, diametrically opposed to each other. Neither of them satisfied my mind perfectly. I was convinced that their views could be brought to a higher synthesis. Form without matter is empty; matter without form is blind."

${ }^{34}$ This characteristic is not only "a streak of pessimism" (BEW 131) discovered by Holmes, but also "an ever fresh sense of wonder at the mystery of the universe" ( $B E W$ 130): "Although I am a Christian and believe in the revelation, yet I too enjoy the sense of wonder, for the simple reason that God has not revealed to us everything, and that His revelation itself is to me a greater mystery than the existence of the universe. As St. Thomas has said, 'This is the final human knowledge of God: to know that we do not know God.' In the end God is the only Theologian worthy of the name" (BEW 130).

${ }^{35}$ What we have here is the understanding that everything is transient and finite, existing in the medium of time, and that everything is composed of contradictions (opposing forces). This is a simple or shortened dialectic. 
It will be noted that this whole "series of counterpoints" $[\ldots]$ does not really move beyond the sphere of nature to the realm of grace. ${ }^{36}$ But grace fulfills nature rather than destroys it. If, therefore, this whole series of counterpoints can be lifted to the sphere of grace, it would enrich one's spiritual life rather than impede it in any way. (BEW 127)

John Wu attributed to his friend Holmes ${ }^{37}$ his sensitivity to that which is within the bondage to the dialectical process of time:

He saw a tendency in me to forget the particular for the universal, the near for the far, the tree for the wood, the human for the divine. (BEW 131)

Although the process of John Wu's conversion to Catholicism ${ }^{38}$ is here not the main issue, ${ }^{39}$ we want still to stress that from the witness of John Wu it was St. Thérèse of Lisieux who made his conversion possible:

He [that is, Mr. Yuan Kia-hoang, a most zealous Catholic ${ }^{40}$ ] gave me [1'] Histoire d'une âme. ${ }^{41}$ I ran through the book and was so deeply impressed by it that I said to myself, "If this book represents Catholicism, I don't see why I should not be a Catholic." For there I found the living synthesis between all pairs of opposites, such as humility and audacity, freedom and discipline, joys and sorrows, duty and love, strength and tenderness, grace and nature, folly and wisdom, wealth and poverty, corporateness and individuality. She seemed to me to combine the heart of the Buddha, the virtues of Confucius, and the

\footnotetext{
${ }^{36}$ Cf. John Wu's FoJ, chapter XXV: "Nature and Grace,” pp. 218-231.

${ }^{37}$ That is Oliver Wendell Holmes, Jr. (1841-1935) was an American jurist who served as an Associate Justice of the Supreme Court of the United States from 1902 to 1932.

${ }^{38} \mathrm{Cf}$. $B E W$ 265: "All that I want to testify here is that a Catholic is never alone in the world; he never suffers or enjoys alone, although he may be living in a desert; he has numberless relatives in Heaven and on earth, many of whom he does not even know; he is an integral member of the Mystical Body of Christ, and his family is but a corporate member of a great family." "Holmes' catholicity has broadened my mind and thus prepared me indirectly to embrace Catholicism, the house with many mansions" (BEW 127-128).

${ }^{39}$ The main part in $B E W$ is chapter "15. The Return of the Prodigal," pp. 224-244.

${ }^{40} \mathrm{Cf}$. SoL VII.

${ }^{41}$ That is The Story of a Soul as the autobiography of Thérèse of Lisieux. It was first published on September 30,1898, a year to the day after her death from tuberculosis at the age of 24, on September 30, 1897. The book was a single volume formed from three distinct manuscripts - manuscripts of different length, written at different times, addressed to different people, and differing from one another in character. The work of unifying these disparate manuscripts was carried out by Pauline, the sister of Thérèse. It was initially published with a limited audience in mind, the Carmelite convents and certain religious personalities, and just 2000 copies of the 475 page book were printed. It quickly became a publishing phenomenon after the canonization of Sister Thérèse of the Child Jesus in 1925. Cf. The Autobiography of Saint Thérèse of Lisieux: The Story of a Soul, translated by John Beevers.
} 
philosophic detachment of Lao Tse. Here was a young Sister who died at twenty-four, and had attained such perfection. What was the secret? How could she realize her individuality so fully if she were not an integral member of the Mystical Body of Christ?

It was through reading this book that I decided to become a Catholic. Grace had touched my heart. (BEW 243)

This passage from $B E W$ is the locus classicus of God's grace touching John Wu's mind and heart. Before his conversion, however, there were some dramatic moments in John Wu's life such as the one testified by him in the following passage:

In 1938 I was to be forty, according to the Chinese way of reckoning age. I had only four years to wait before I could have a concubine with the authorization of my wife! The promised land was in sight, but the all-merciful Father had better plans. Just a few days before 1938, He snatched me from the grip of the Devil and saved me from myself. I was received into the Holy Catholic Church on December 18, 1937; and the nightmare which had lasted for more than seven long years came to an end. (BEW 137)

John Wu's last instructor before his conditional baptism was Father Georges Germain, the then Rector of the Aurore University in Shanghai ${ }^{42}$ :

On December 18, 1937 he gave me conditional Baptism in the little chapel of Our Lady attached to the University. Everything was done quietly. Only Yuan and my son Thomas were present. On the next morning I received my First Communion in the same chapel. (BEW 243-245)

Let me quote another testimony of John $\mathrm{Wu}$ in which the transforming power of God's grace was at work not only in the life of John $\mathrm{Wu},{ }^{43}$ but also the quality of his marriage and his whole family:

\footnotetext{
${ }^{42}$ His Chinese name was Cai Ermeng 才爾孟 (1895-1978). As a young priest, he became Professor of the History of Diplomatic Relations in Aurora University, Shanghai, and he was Rector of the University for many years. His deep understanding of men and his humorous outlook on life combined to make him an outstanding personality attracting both admiration and affection, within the university and in the world at large. During the Communist rise, he was arrested, tried, and imprisoned. Unexpectedly his stay in prison proved short. This clemency was generally attributed to the influence of former Aurora students who, though high in the Communist hierarchy, had not lost their reverence for their old rector. Cf. "Rev. GERMAIN, Georges SJ", archives.catholic.org.hk/InMemoriam/Clergy-Brother/G-Germain.htm (accessed on 18 July 2019).

${ }^{43} \mathrm{Cf}$. $B E W$ 317: "By nature I am a coward, but by grace I have felt in times of danger like a baby in the arms of its mother. And since Mary is my Mother, how could I help feeling grateful for her ever-watchful care of me, in season and out of season?"
} 
Since I became a Catholic, my family has followed me into the Church, and Christ the King has been enthroned in our house. My wife and I have found our rest in the Sacred Heart of Christ. We are bound together by a common Love. As we progress in the love of God, we progress in the love of each other. For the past few years, my wife and I have been receiving Holy Communion practically every day [...]. O Christ, our hearts are united in the Love of You, and how can we ever be separated so long as neither of us is separated from You? ${ }^{44}$ In Your Sacred Heart we have found our Home; who says that we are exiles? O God, Your will is our destiny, and to do Your will is our freedom!

God has opened my eyes gradually to the interior qualities of my wife, to such a degree that, whereas I formerly thought she was not worthy of me, now I realize that I am not worthy of her. Christ has become the living bond between us. [...] We only adore the Christ that we have in common, and it is He who binds us together. As each of us comes closer to Christ, we find that we are coming closer to each other. (BEW 140-141)

The whole $B E W$ permeates the atmosphere of John Wu's experience of grace as the love and mercy given to him by God because God desires him to have it, $^{45}$ not because of anything he has done to earn it. It was to him the condescension and benevolence shown by God toward him and his family as a generous, free and totally unexpected and undeserved gift:

I don't rely only on my nature, but on His grace. His grace has changed my natural changeableness into a feeling tentacle for discovering every day new beauties of Christ and of His Church, thus ministering unto my constancy. Has St. Paul not said, "For when I am weak, then I am strong"? Shall I not say, "When I am changeable, then I am constant"? The Lord has transmuted my natural fickleness into supernatural fidelity! (BEW 267)

John Wu was "a soldier of Christ" ( $B E W 254)$ to whom

God has opened [his] eyes to one fundamental truth: Nothing really good can be accomplished without genuine suffering. The higher the achievement, the higher the price. There is no greater thing than sanctity, and therefore one must be ready to pay the highest price. Even the Son of God had to pay the

${ }^{44}$ The echo of the words of St. Paul in Romans 8:35: "What will separate us from the love Christ has for us? Can trouble, distress, persecution, hunger, nakedness, danger, or violent death separate us from his love?"

${ }^{45}$ Cf. $B E W$ 228-229: "To be converted, one must first know himself to be perverted. For the first step down in our own estimation is the first step up towards God. My pride was already crushed, but it was too painful to continue that condemnation of myself. Consequently, I closed the Bible like a child whose finger lad been burnt by accident. I wanted to read something lighter to distract my mind." 
supreme price for His Christhood, had to swallow the bitter cup, had to be the Man of Sorrow before He could redeem mankind from its sins. If one wants to follow Christ but at the same time shrinks from pain, it is like crying for the moon. (BEW 258)

In accepting from God a ladder of a true Christian faith, John Wu's was also given the gift of tears. ${ }^{46}$ To Christian mystical tradition, tears are a gift of grace from God. Thus, the shedding of tears arises from the heart that reveals an openness and vulnerability. The fruit of tears is always joy. ${ }^{47}$

We want to finish this paragraph on John Wu's most important ladder of moving beyond East and West, that is, a true Christian faith as a pure gift and an undeserved grace given by God Himself, with a short reflection of his theology of non-Christian religions ${ }^{48}$ in China, that is, Daoism, Confucianism, and Buddhism. It is very interesting that John $\mathrm{Wu}$ divided his $B E W$ into two parts: Part one from chapter1 to chapter 11 (pp. 3-145) and part two

\footnotetext{
${ }^{46}$ For example $B E W$ 235-236: "Hardly had I finished the last paragraph [on the sinning woman at Simon's house (cf. Luke 7:36-50)] when I burst into a violent fit of weeping myself. I said, "Jesus, I, too, am a prostitute. God has endowed me with beauties of soul and intellect, and I have wasted them on the search for worldly honors and material riches. In the world of politics and in social life, I too have been forced to pretend a pleasure I did not feel, and to show a smiling face to those whom I despised. And all the time I have been neglecting you, my Redeemer and my Spouse. Forgive me, Jesus, and let me anoint you with my tears! And forgive all my dear sisters, those poor sing-song girls, who are much better than I am. Turn them into your saints!" For other instances, see $B E W 255,260,308,316,335$, and 340.

${ }^{47}$ Cf. $B E W$ 215: "Joy is perfection, says Spinoza; I may add, joy and pleasure are as wide apart from each other as heaven and earth" and $B E W$ 211: "Only when you have tasted sickness can you realize with all the muscles of your body what a great joy it is just to be in normal health."

${ }^{48}$ Today the Catholic Church has its Nostra Aetate (Latin: "In our Age"), that is, the "Declaration on the Relation of the Church with Non-Christian Religions" of the Second Vatican Council as an official and guiding document. This declaration was promulgated on October 28, 1965, by Pope Paul VI. In the "Introduction," the Declaration says describes the unity of the origin of all people, and the fact that they all return to God; hence their final goal is also one. It mentions the eternal questions which have racked men's brain since the beginning, and how the various religious traditions have tried to answer them. In part two "Hindus, Buddhists, and other religions," it shortly provides some of the answers that Hindus, Buddhists, and members of other faiths have suggested for such philosophical questions. It notes the willingness of the Catholic Church to accept some truths present in other religions in so much as they reflect Catholic teaching and may lead souls to the Christ. Part three speaks of "Muslims" and part four of "Jews." In "Conclusion," the Declaration states that all men are created in God's image, and that it is contrary to the teaching of the Church to discriminate against, show hatred towards or harass any person or people on the basis of color, race, religion, condition of life and so on. Cf. the text of "Declaration": www.vatican.va/archive/hist_councils/ii_vatican_council/documents/vat-ii_decl_ 19651028_nostra-aetate_en.html (accessed on 18 July 2019).
} 
from chapter 12 to chapter 21 with "Epilogue" and "Explanations and Acknowledgements" (pp. 149-364). At the beginning of the part two of his $B E W$, that is, chapter 12: "The Religions of China," he writes as follows:

Now that I am approaching the end of my spiritual wanderings, I must speak in some detail of the religions of China. They constitute my moral and religious background, and hence they form an integral part of the development of my spiritual life. They are an important portion of the natural dowry with which God had endowed me in preparation for my marriage with Christ. I often think of myself as a Magus from China who lays before the Divine Infant in the arms of the Blessed Virgin the gold of Confucianism, the musk ${ }^{49}$ of Taoism, and the frankincense of Buddhism. At a single touch by His hands, whatever is false in them is purified, and whatever is genuine is transmuted into supernatural values. ( $B E W 149)$

John Wu's conversion to Christianity ${ }^{50}$ in the form of Catholicism meant to him the ultimate acceptance of the absolute truth given to him by God. The offering of Chinese religions was an act of adoration of God in His son Jesus Christ as God's ultimate personal truth who became man. That is why John can say:

[Christianity] is more native to me than the Confucianism, Taoism and Buddhism $^{51}$ in whose milieu I was born. I am grateful to them, because they have served as pedagogues ${ }^{52}$ to lead me to Christ. Christ constitutes the unity of my life. It is thanks to this unity that I can rejoice in being born yellow and educated white. (BEW 12)

${ }^{49}$ It is a substance secreted in a glandular sac under the skin of the abdomen of the male musk deer, having a strong aromatic odor, and used in perfumery. Cf. Matthew, Chapter 2 where three gifts of magi are explicitly identified, that is, gold, frankincense, and myrrh. Many different theories of the meaning and symbolism of the gifts have been brought forward. While gold (king's majesty) is fairly obviously explained, frankincense (worship), and particularly myrrh (Jesus' death), are much more obscure. Interestingly, in his text John Wu exchanged "myrrh" (moyao 沒藥) with “musk” (shexiang 噟香).

${ }^{50}$ Cf. SoL 29: "To me as a Chinese, the great thing about Christianity is that it combines the profound mysticism of Lao Tzu with the intense humanism of Confucius," or p. 30: "Only Christianity can satisfy my mind completely, because its idea of God is at once broad and personal. And it is Thérèse who has confirmed my faith in my Religion, for her mind is as subtle and detached as that of Lao Tzu, while her heart is as affectionate and cordial as that of Confucius."

${ }^{51} \mathrm{Cf}$. $B E W$ 185: "Now that I think of it, I have inherited from Buddhism an intense longing for the "Other Shore," which is but another name and a faint foreshadowing of the Kingdom of God which is within us."

${ }^{52}$ Cf. BEW 48: "Whenever I think of Confucius and Mencius, Buddha and Lao Tse, I am inclined to call them - as St. Justin Martyr called Socrates, Plato, and Aristotle-Pedagogues to lead men to Christ." 
Thus, "[...] nothing human can be greater than these [three religions, that is, Confucianism, Taoism, and Buddhism], but Christianity is divine" ( $B E W$ 12). Yes, Confucianism, Taoism, and Buddhism were John Wu's pedagogues, teachers and educators, however, in respect to his Christian faith as pure gift of God and as an "ultimate concern" (Paul Tillich ${ }^{53}$ ) of his life, he had only "one Teacher, the Christ" (Matthew 23:10).

\section{BIBLIOGRAPHY}

\section{PRIMARY SOURCES}

$B E W=\mathrm{Wu}$, John. Beyond East and West. Sheed and Ward, 1951.

FoJ $=$ Wu, John. Fountain of Justice: A Study in the Natural Law. Mei Ya Publications Inc., 1971.

SoL $=\mathrm{Wu}$, John. The Science of Love: A Study in the Teachings of Thérèse von Lisieux. Catholic Truth Society, 1941.

\section{SECONDARY LITERATURE}

Gentile, Emilio. Politics as Religion. Princeton University Press, 2006.

Harris, Maxine. The Loss That Is Forever: The Lifelong Impact of the Early Death of a Mother or Father. Penguin Books, 1995.

Hathaway, Ronald F. Hierarchy and the Definition of Order in the Letters of Pseudo-Dionysius: A Study in the Form and Meaning of the Pseudo-Dionysian Writings. Nijhoff, 1969.

Healey, Charles J. Christian Spirituality: An Introduction to the Heritage. St. Paul's Alba House Bookstore, 1999.

Keegan, Nicholas M. "From Chancery to Cloister: the Chinese Diplomat who became a Benedictine Monk." Diplomacy \& Statecraft. Routledge, part of the Taylor \& Francis Group, vol. 10, no. 1, 1999, pp. 172-185.

Marcel, Gabriel. Homo Viator: Introduction to a Metaphysic of Hope. French original: 1945. Translated by Emma Craufurd. Harper \& Row, 1962.

Raveis, Victoria H., Karolynn Siegel, and Daniel Karus. “Children's Psychological Distress Following the Death of a Parent." Journal of Youth and Adolescence, vol. 28, no. 2, 1999, pp. 165-180.

Thérèse of Lisieux. The Autobiography of Saint Therese of Lisieux: The Story of a Soul. Translated by John Beevers. Doubleday Religious Publishing Group, 1989.

Tillich, Paul. Dynamics of Faith. Harper \& Row, 1957.

Tsakiridis, George. Evagrius Ponticus and Cognitive Science: A Look at Moral Evil and the Thoughts. Pickwick Publications, 2019.

Vetterling-Braggin, Mary (editor). "Femininity," "Masculinity," and "Androgyny": A Modern Philosophical Discussion. Adams, 1982.

Welch, Patricia Bjaaland. Chinese Art: A Guide to Motifs and Visual Imagery. Tuttle Publishing, 2008.

\footnotetext{
${ }^{53}$ Cf. his Dynamics of Faith (1957).
} 


\section{„POZA WSCHODEM I ZACHODEM”- JAKIEJ „DRABINY” UŻYŁ JOHN WU DO OSIĄGNIĘCIA TEGO CELU?}

Streszczenie

John Wu Jingxiong (1899-1986) był dyplomatą, uczonym i autorytetem w dziedzinie prawa międzynarodowego. Był także wybitnym chińskim katolikiem. Jego duchowa autobiografia Beyond East and West (1951) przypomina Wyznania św. Augustyna poprzez poruszający opis nawrócenia Johna Wu na katolicyzm w 1937 r. i jego wczesne lata jako katolika. Sam tytuł autobiografii Wu wskazuje na jego duchowy ideał, który pozwala ludziom wykraczać poza kulturowe osobliwości (czy to zachodnie, chińskie czy inne). John Wu znalazł mądrość w wielkich chińskich tradycjach, tj. w konfucjanizmie, daoizmie i buddyzmie, wskazując na ich uniwersalne prawdy, które ostatecznie pochodzą od Chrystusa i w nim się wypełniają. Autor tego artykułu szukał uniwersalnych cech Johna Wu, które wykraczają poza jakąkolwiek kulturę i które metaforycznie nazwał „drabiną”. Znalazł potrójną drabinę, tj. wiarę chrześcijańską, przyjaźń wraz ludzką i boską miłością i prawo naturalne.

Słowa kluczowe: John Wu; Beyond East and West; duchowa autobiografia; wiara chrześcijańska; przyjaźń; ludzka i boska miłość; prawo naturalne 